\title{
Corporate Governance and Involuntary Delisting: Empirical Evidence from China
}

\author{
Muhammad Nasir Malik ${ }^{1}$, Xia Xinping ${ }^{1} \&$ Rizwan Shabbir ${ }^{1}$ \\ ${ }^{1}$ School of Management, Huazhong University of Science \& Technology, Wuhan, China \\ Correspondence: Muhammad Nasir Malik, School of Management, Huazhong University of Science \& \\ Technology, Wuhan, China. Tel: 861-355-466-3700. E-mail: mnmalik@gmail.com
}

Received: March 10, 2014

Accepted: March 28, 2014

Online Published: May 25, 2014

doi:10.5539/ijef.v6n6p247

URL: http://dx.doi.org/10.5539/ijef.v6n6p247

\begin{abstract}
This study aims to investigate the change in corporate governance structure of a firm in China as it approaches involuntary delisting. To this end, we try to identify corporate governance characteristics that have the most significant impact on probability of involuntary delisting at three years prior to the event, two years prior to the event, and one year prior to the event. The corporate governance characteristics examined in this study are board characteristics (board activity, board size, board independence, and presence of audit committee) and ownership characteristics (shareholder activism, ownership concentration, and insider ownership). We use logistic regression analysis on a match pair sample of surviving and delisting firms and evaluate how the governance characteristics vary over time for the two sets of firms. Our results confirm a widening gap between governance structures of delisting and surviving firms as the former approach delisting event.
\end{abstract}

Keywords: involuntary stock delisting, corporate governance, ownership characteristics, board characteristics

\section{Introduction}

Delisting, and specifically involuntary delisting, has been a subject of increasing attention in recent times. Exchanges around the world require compliance with certain quantitative and/or qualitative criteria as a continuing listing requirement. These criteria may include restrictions on minimum number of stockholders, minimum trading volumes, minimum stock prices, adequate financial disclosures, and satisfactory financial conditions. In addition, an exchange may delist a firm based on any other event that renders continued listing of a stock inappropriate. Stock exchanges impose such requirements because their own repute hinges on the quality of stocks traded on their floor.

Delisting, though not exactly the same as bankruptcy, has a significant negative impact both for the shareholders and the firm. Inter alia, O'Donnell (1969) and Jarrell (1984) found an average decline of $9 \%$ in the market value of delisted stocks while Sanger and Peterson (1990) confirmed average abnormal returns of $-8.5 \%$ around delisting. More recently, Panchapagesan and Werner (2004) noted a decline of about 50\% in the median stock price coupled with a threefold increase in bid-ask spreads and a two third decline in trading volumes after delisting. Macey, O'Hara and Pompillo (2005) shown that upon delisting the stock prices are reduced to almost half on average, percentage bid-ask spreads and volatility increases. Similarly, Harris, Panchapagesan and Werner (2008) found increasing spreads, declining trading volumes and increased intraday return volatility for governance related delisting. In short, involuntary delisting events impose significant costs on the shareholders making it an area worth investigating.

Unfortunately, there is very little evidence on the association of corporate governance with the likelihood of stock delisting across the globe. The dearth of literature, therefore, provides plausible basis for examining this association. There are few studies which have tested the efficacy of Altman (1968) and Ohlson (1980) bankruptcy prediction model in China. However, none of these studies have employed corporate governance variables to predict delisting in Chinese context. This research attempts to provide a novel analytical framework by introducing corporate governance variables in a delisting prediction model. The research adds value by analyzing whether and how the governance characteristics of a firm change over time and with respect to a set of surviving firms.

Generally, delisting occurs immediately subsequent to violation of exchange specified criteria. However, in case 
of Shanghai Stock Exchange (SSE) and Shenzhen Stock Exchange (SZSE) the firms are initially given a delisting risk warning. Subsequently, if the firm does not rectify the circumstances which were basis of delisting risk warning, it is delisted from the exchange. This unique delisting process and peculiar governance characteristics of Chinese firms augment the need for investigating governance related predictors of delisting events in China.

This study uses corporate governance characteristics in developing a logistic regression model to predict the probability of involuntary delisting of a firm from SSE and SZSE. The governance characteristics used to develop the model are shareholder activism, board activity, board size, board independence, audit committee, insider ownership and ownership concentration.

\section{Literature Review}

There is a voluminous amount of literature linking corporate governance structures with firm performance and adverse organizational outcomes like bankruptcy or takeovers (Daily \& Dalton, 1994; Weir, Laing, \& McKnight, 2002; Ho \& Williams, 2003; Ajinkya, Bhojraj, \& Sengupta, 2005; Goktan, Kieschnick, \& Moussawi, 2006). Much of this literature contends that likelihood of an adverse organizational outcome is significantly associated with the effectiveness of corporate governance. Drawing from this literature, we attempt to analyze the association between delisting events in China and corporate governance characteristics.

Gillan and Stark (1998) suggest shareholder activism represent shareholders' response process on a continuum which varies from simplest form of opinion expression to the market for corporate control. Karpoff (2001) found the empirical results on shareholder activism to be mixed. Proponents of shareholder activism argue that active shareholders prevent managerial complacency and help the firms to outperform in the long term. The opposing argument regards shareholder activism as a disruption. Black (1998) and Romano (2000) suggest that shareholder activism has very little to no effect on the corporate performance. The effect of shareholder activism on the probability of delisting is not analyzed in the literature. This research adds a new dimension to the existing literature on corporate governance and delisting events.

In the related literature board activity is frequently measured as frequency or cumulative frequency of board meetings in a given period. Board activity is expected to be positively related with future firm performance as more active boards indicate better governance practices. However, board activity is expected to be negatively related with past firm performance as frequency of board meetings may raise in response to the adverse circumstances of the firms. Vafeas (1999) shows that increased board activity is usually followed by periods of poor firm performance while firms with extraordinary board activity have better odds of combating the adverse situations. Charitou, Louca, \& Vafeas (2007) found that board activity is significantly related to the probability of delisting. We expected the firms to experience higher board activity as they approach involuntary delisting.

Audit committee is an operating committee of the board of directors of a company charged with the responsibility of oversight of financial reporting practices, ensuring external auditor independence and protecting shareholders' interests. In general, presence of an audit committee should induce better management practices resulting in improved firm performance and reduced odds of involuntary delisting from an exchange owing to non-compliance of reporting regulations and requirements. Dechow, Sloan and Sweeny (1996) show that presence of an audit committee is positively associated with prevention of fraudulent activities. Klein (1998) and Klein (2002) report reduced earnings management and improved firm performance as a result of audit committee presence. Mangena and Chamisa (2008) show the audit committee presence to have a significant negative impact on delisting events in South Africa. We expect the presence of audit committee to be negatively associated with the probability of delisting in China.

Board size is determined by the number of directors serving on the board of directors of a company. Jensen (1993) considers board size to be an important board characteristic in determining overall effectiveness of the corporate governance mechanism. The argument in favor of larger board size posits that larger boards represent a multi-dimensional body of knowledge and are better equipped to combat the complex and dynamic challenges. However, larger boards may suffer from communication and coordination issues resulting in delayed decision making. Inter alia, Goodstein, Gautum and Boeker (1994), Beasley (1996), Karamanou and Vafeas (2005) provide support for larger boards. On the other hand, Eisenberg, Sundgren and Wells (1998), Jensen (1993) and Yermack (1996) contend that larger boards are negatively associated with firm performance. Prior literature suggests that the board size may be positively or negatively associated with the probability of delisting.

Board independence refers to the number of non-executive directors serving on the board of a company. A larger percentage of non-executive, non-related directors would indicate a more independent board. Independent boards are less likely to patronize managerial opportunism and, therefore, should perform a better job of protecting 
shareholder's interest. Inter alia, Beasley (1996), Klein (2002) and Raheja (2005) contend that board independence is associated with improved firm performance. Another strand of related research supported by Weir et al., (2002), Ho and Williams (2003), Fama and Jensen (1983) and Mangena and Pike (2005) suggest that the inclusion of non-executive directors improves the board's effectiveness.

Ownership concentration refers to the cumulative percentage shareholding of block shareholders. Ownership structure is another important determinant of corporate governance mechanism (Shleifer \& Vishny, 1986). Intuitively, a large number of small shareholders will lack the incentive and control over managerial decision making. On the other hand, few large shareholders will find it easy and have a better incentive to control management. The empirical evidence on ownership concentration is mixed but interesting. A large body of research supported by Shivdasani (1993), Karamanou and Vafeas (2005), Haniffa and Hudaib (2006) suggest that ownership concentration is positively associated with firm performance and enhances effectiveness of corporate governance. On the other hand Baek, Kang and Park (2004) find ownership concentration to be inversely related to firm performance. Fama and Jensen (1983) posit that very high ownership concentration may be detrimental to minority stakeholders. Still, Weir et al. (2002) find ownership concentration to be insignificant in explaining firm performance. We tentatively expect that ownership concentration is negatively associated with probability of delisting in China.

Similar to ownership concentration, insider ownership provides another very important channel to realign management goals with those of shareholders (Morck, Shleifer, \& Vishny, 1988). Insider ownership refers to the cumulative percentage shareholding of the executives. Intuitively, insider ownership should be positively related to firm performance as the agency costs are minimized through a natural interest alignment process. However, very high levels of insider ownership may allow managers the freedom to expropriate corporate assets for personal benefits. Prior literature including McConnell and Servaes (1990), Jensen (1993) and Short and Keasey (1999) provide evidence that insider ownership improves firm performance, reduce agency costs and mitigates the conflict of interest. In line with the prior literature, we expect that insider ownership is negatively related to incidences of involuntary delisting in China.

\section{Data and Methodology}

Inter alia, Mangena and Chamisa (2008), Charitou et al. (2007), and Daily and Dalton (1994) have used a matched pair sampling technique to analyze similar research problems. Following these researches, we also use match pair sample as "it provides a parsimonious means of controlling for certain potentially important confounding firm-specific characteristics" (Peasnell, Pope, \& Young, 2001). For sample selection, we use industry classification and firm size as the two criteria. The intuition behind this approach is that firms in similar industry groups tend to have similar governance structures and practices. Further, the governance practices of large companies differ significantly from governance practices of smaller companies. We identify the second level CSRC (Note 1) industry code of each delisted firm in our sample. For each delisted firm, we then gathered a list of all the firms operating in that industry classification in the corresponding year. Finally, we select the firm with similar asset base, as of delisted firm, three years prior to delisting as the match pair of each delisted firm. This approach result in a time, industry and size matched sample of delisting and surviving firms.

We use an exhaustive sample of the firms involuntarily delisted from SSE and SZSE between 1999 and 2012. During this period there are a total of 81 incidences of stock delisting representing 77 different companies. We collected the data on corporate governance structure for this sample at three different time periods: three years prior to delisting, two years prior to delisting and one year prior to delisting.

Table 1. Analysis of sample of firms delisted between 1999 and 2012 in China

\begin{tabular}{lcc}
\hline \multicolumn{1}{c}{$\begin{array}{c}\text { Basis of Analysis } \\
\text { Age at Delisting }\end{array}$} & Number & Percentage \\
\hline Less than 2 Years & 0 & 0.00 \\
Between 2 to 4 Years & 1 & 1.23 \\
Between 4 to 6 Years & 5 & 6.17 \\
Between 6 to 8 Years & 21 & 25.93 \\
Between 8 to 10 Years & 22 & 27.16 \\
Between 10 to 12 Years & 18 & 22.22 \\
Between 12 to 14 Years & 4 & 4.94 \\
More than 14 Years & 10 & 12.35 \\
\hline
\end{tabular}




\begin{tabular}{lcc}
\hline \multicolumn{2}{c}{ Reason for Delisting } & \\
\hline Merger & 23 & 28.40 \\
Privatization & 7 & 8.64 \\
Stock Replacement & 2 & 2.47 \\
Non-Disclosure of Periodic Reports & 4 & 4.94 \\
Operating Losses & 45 & 55.56 \\
\hline
\end{tabular}

We use logistic regression to analyze the effect of corporate governance characteristics on delisting phenomenon in China. For this purpose we use a dummy dependent variable, with dichotomous outcomes, to represent delisting events in China with the values of ' 1 ' for delisting and ' 0 ' for control or surviving firms. Traditionally, the researchers have used simple linear regression to address such problems (Peng et al, 2002). But Cleary and Angel (1984), Cox and Snell (1989), Cabrera (1994) and Long (1997) suggested that logistic regression is most suitable for problems involving dummy dependent variables. Moreover, the application of logistic regression does not require the strict assumptions of linearity, normality and equal variance (Burns \& Burns, 2009). We estimate the following logistic model:

$$
P(\text { delist })=b_{1} \text { S.Act } .+b_{2} \text { B.Act. }+b_{3} \text { A.Com } .+b_{4} \text { B.Size. }+b_{5} \text { B.Ind }+b_{6} \text { O.Conc. }+b_{7} \text { I.Own } .
$$

where S.Act denotes shareholder activism and is measured as the percentage of shareholders participating in the annual general meeting; B.Act denotes board activity and is measured as the number of meetings of the board of directors in the preceding year; A.Com denotes audit committee and represents the presence or absence of audit committee; B.Size denotes board size and is measured as the number of directors in the board; B.Ind denotes board independence and is measured as the percentage of non-executive directors in the board of a company; O.Conc denotes ownership concentration and is measured as the percentage of ownership held collectively by the five largest shareholders of the company; and I.Own denotes insider ownership and is measured as the percentage of combined shareholding of board of directors, board of supervisors and executives. We compare the governance characteristics at three successive periods - three years prior to delisting (T-3), two years prior to delisting (T-2), and one year prior to delisting (T-1) - leading up to the actual delisting event.

\section{Empirical Results}

Table 2 provides the means for governance characteristics of the delisted firms at three year, two year and one year prior to delisting. Shareholder activism has declined successively from $52.20 \%$ presence of shareholders in AGM to $45.95 \%$ presence for delisted firms. Board activity increased from an average of 6.33 meetings per year to around 8 meetings per year from period T-3 to period T-2 but then remained stable at that level. Only $12.82 \%$ of the sample firms had an audit committee at period T-3. An additional $11 \%$ firms experienced constitution of audit committee immediately preceding delisting. Overall the board size of delisting firms reduced from 8.74 members to 6.92 members between period T-3 and period T-1. Board independence increased significantly from only $14.25 \%$ independent directors to $30.40 \%$ independent directors on the board immediately before delisting. Ownership concentration and insider ownership both declined for the delisted firms as the approached the delisting event in China. Insider ownership reduced from $3.21 \%$ to $1.31 \%$ while ownership concentration reduced from $50.07 \%$ to $46.99 \%$ between period T-3 and period T- 1 . It is interesting to note that governance characteristics for delisted firms exhibit either increasing or decreasing trend over the three years period preceding delisting.

Table 2. Comparison of means of predictor variables

\begin{tabular}{llllllll}
\hline & $\begin{array}{l}\text { Shareholder } \\
\text { Activism }\end{array}$ & $\begin{array}{l}\text { Board } \\
\text { Activity }\end{array}$ & $\begin{array}{l}\text { Audit } \\
\text { Committee }\end{array}$ & Board Size & $\begin{array}{l}\text { Board } \\
\text { Independence }\end{array}$ & $\begin{array}{l}\text { Ownership } \\
\text { Concentration }\end{array}$ & $\begin{array}{l}\text { Insider } \\
\text { Ownership }\end{array}$ \\
\hline Delisted & & & & & & & \\
T-1 & 45.9455 & 8.0714 & 0.2381 & 6.9286 & 30.3987 & 46.9985 & 1.3109 \\
T-2 & 47.5855 & 8.3095 & 0.2143 & 7.2381 & 18.9654 & 47.5050 & 2.0697 \\
T-3 & 52.1969 & 6.3333 & 0.1282 & 8.7436 & 14.2554 & 50.0717 & 3.2184 \\
Surviving & & & & & & & \\
T-1 & 63.1962 & 6.9459 & 0.1892 & 7.2703 & 34.0544 & 57.8061 & 8.3765 \\
T-2 & 57.3856 & 6.0625 & 0.1250 & 7.7500 & 18.1525 & 57.6551 & 8.2635 \\
T-3 & 55.7815 & 6.1154 & 0.0385 & 8.5385 & 11.9948 & 57.2765 & 8.6572 \\
\hline
\end{tabular}


While the governance characteristics of delisting firms exhibit certain trends, the governance characteristics of surviving firms do not vary much overall. There is no visible decline or increase in board activity, board size, ownership concentration and insider ownership for the surviving firms in the three year period. Contrary to delisting firms, the surviving firms experience an increase in shareholder activism over the study period with participation rates increasing marginally from $55.78 \%$ to $63.20 \%$. Audit committee and board independence for surviving firms show a similar trend, compared to delisting firms, but with a greater magnitude.

Table 3 presents the difference in mean values of each governance characteristic for the delisting and surviving firms at the three different periods under study. It is evident that the delisting and surviving firms exhibit different behavior for most of the governance characteristics and the differential increases as the delisting firms approach the delisting event. Shareholder activism for surviving firms is slightly higher (3.58\%) compared to delisting firms at period $\mathrm{T}-1$, however, the difference is very large $(17.25 \%)$ immediately preceding delisting. The board activity of delisted and surviving firms is almost similar at period T-1 but it slightly increases for delisting firms in the next two years. Presence of audit committee is a more frequent occurrence in delisting firms and the behavior of two groups does not change much on this dimension. Delisting firms have larger boards three years prior to delisting, however, in the next two years the surviving firms have larger boards. Delisting firms have more independent boards three years prior to delisting but there boards are less independent compared to surviving firms immediately before delisting. Surviving firms have greater ownership concentration and insider ownership compared to delisting firms and the gap between these two groups widens further as the delisting firms approach actual delisting event.

Table 3. Comparison of difference of means of predictor variables

\begin{tabular}{llllllll}
\hline & $\begin{array}{l}\text { Shareholder } \\
\text { Activism }\end{array}$ & $\begin{array}{l}\text { Board } \\
\text { Activity }\end{array}$ & $\begin{array}{l}\text { Audit } \\
\text { Committee }\end{array}$ & \multirow{2}{*}{ Board Size } & $\begin{array}{l}\text { Board } \\
\text { Independence }\end{array}$ & $\begin{array}{l}\text { Ownership } \\
\text { Concentration }\end{array}$ & $\begin{array}{l}\text { Insider } \\
\text { Ownership }\end{array}$ \\
\hline T-1 & -17.2507 & 1.1255 & 0.0489 & -0.3417 & -3.6557 & -10.8076 & -7.0656 \\
T-2 & -9.8001 & 2.2470 & 0.0893 & -0.5119 & 0.8129 & -10.1501 & -6.1938 \\
T-3 & -3.5846 & 0.2179 & 0.0897 & 0.2051 & 2.2606 & -7.2047 & -5.4388 \\
\hline
\end{tabular}

Note. $*$ Difference $=$ Delisting - Surviving.

Table 4 gives a comparison of tests of equality of group means for governance characteristics of delisting and surviving firms at period T-3, T-2 and T-1. These statistics provide insights into how the governance characteristics of delisting and surviving firms have changed over time. We report the results of non-parametric tests as they are more conservative and more suitable for groups with different variances. The results show that the means of only two characteristics, ownership concentration and insider ownership, are significantly different three years prior to delisting. However, the means of shareholder activism, ownership concentration and insider ownership are significantly different for delisting and surviving firms two years prior to delisting and one year preceding delisting event. Board activity is significantly different for the two groups at two years prior to delisting only. Similar results are obtained from Kolmogorov-Smirnov test.

Table 4. Comparison of tests of equality of group means at period T-3, T-2 and T-1

\begin{tabular}{llllllll}
\hline & $\begin{array}{l}\text { Shareholder } \\
\text { Activism }\end{array}$ & $\begin{array}{l}\text { Board } \\
\text { Activity }\end{array}$ & $\begin{array}{l}\text { Audit } \\
\text { Committee }\end{array}$ & Board Size & $\begin{array}{l}\text { Board } \\
\text { Independence }\end{array}$ & $\begin{array}{l}\text { Ownership } \\
\text { Concentration }\end{array}$ & $\begin{array}{l}\text { Insider } \\
\text { Ownership }\end{array}$ \\
\hline Mann-Whitney U & & & & & & & \\
T-3 & 415.000 & 504.000 & 461.500 & 452.500 & 473.500 & $* 360.000$ & $* 342.000$ \\
T-2 & $* * 430.500$ & $* 515.000$ & 612.000 & 585.500 & 662.000 & $* * 397.000$ & $* * 368.500$ \\
T-1 & $* * 343.500$ & 730.000 & 739.000 & 752.000 & 711.000 & $* * 439.000$ & $* 585.000$ \\
Kolmogorov-Smirnov Z & & & & & & \\
T-3 & .911 & .405 & .354 & .810 & .304 & $* 1.317$ & $* 1.468$ \\
T-2 & $* 1.471$ & $* 1.287$ & .381 & 1.065 & .545 & $* * 1.744$ & $* * 1.788$ \\
T-1 & $* * 2.089$ & .845 & .217 & .405 & .674 & $* * 1.864$ & $* 1.390$ \\
\hline
\end{tabular}

Note. ${ }^{* *}$ significant at $1 \%$ level, $*$ significant at $5 \%$ level. 
Table 5 provides the results of ANOVA test for comparison of group means of governance characteristics of delisting firms at period T-3, T-2 and T-1. We expect the governance characteristics to change significantly over time as the delisting firms approach the actual delisting event. We conclude that the board activity, board size, board independence and insider ownership changes significantly for the delisting firms between period T-3 to period T-1.

Table 5. Change in governance characteristics of delisted firms

\begin{tabular}{|c|c|c|c|c|}
\hline & & $\mathrm{df}$ & $\mathrm{F}$ & Sig. \\
\hline \multirow[t]{3}{*}{ Shareholder Activism } & Between Groups & 2 & 1.961 & .145 \\
\hline & Within Groups & 120 & & \\
\hline & Total & 122 & & \\
\hline \multirow[t]{3}{*}{ Board Activity } & Between Groups & 2 & 2.577 & .080 \\
\hline & Within Groups & 120 & & \\
\hline & Total & 122 & & \\
\hline \multirow[t]{3}{*}{ Audit Committee } & Between Groups & 2 & .843 & .433 \\
\hline & Within Groups & 120 & & \\
\hline & Total & 122 & & \\
\hline \multirow[t]{3}{*}{ Board Size } & Between Groups & 2 & 4.294 & .016 \\
\hline & Within Groups & 120 & & \\
\hline & Total & 122 & & \\
\hline \multirow[t]{3}{*}{ Board Independence } & Between Groups & 2 & 4.791 & .010 \\
\hline & Within Groups & 120 & & \\
\hline & Total & 122 & & \\
\hline \multirow[t]{3}{*}{ Ownership Concentration } & Between Groups & 2 & .515 & .599 \\
\hline & Within Groups & 120 & & \\
\hline & Total & 122 & & \\
\hline \multirow[t]{3}{*}{ Insider Ownership } & Between Groups & 2 & 3.416 & .036 \\
\hline & Within Groups & 120 & & \\
\hline & Total & 122 & & \\
\hline
\end{tabular}

Table 6 highlights the variables that are most significant in predicting the probability of delisting at different time periods leading up to the actual delisting event in a logistic regression setting. Shareholder activism, board activity, board independence and insider ownership are significant one year prior to delisting. Board activity, ownership concentration and insider ownership are significant two years prior to delisting and ownership concentration and insider ownership are significant one year prior to delisting. Insider ownership significantly affects the probability of delisting at all three time periods under study.

Table 6. Comparison of significant logistic variables at period T-3, T-2 and T-1

\begin{tabular}{llllllll}
\hline & $\begin{array}{l}\text { Shareholder } \\
\text { Activism }\end{array}$ & $\begin{array}{l}\text { Board } \\
\text { Activity }\end{array}$ & $\begin{array}{l}\text { Audit } \\
\text { Committee }\end{array}$ & $\begin{array}{l}\text { Board } \\
\text { Size }\end{array}$ & $\begin{array}{l}\text { Board } \\
\text { Independence }\end{array}$ & $\begin{array}{l}\text { Ownership } \\
\text { Concentration }\end{array}$ & $\begin{array}{l}\text { Insider } \\
\text { Ownership }\end{array}$ \\
\hline $\mathrm{T}-3$ & .046 & -.023 & -1.184 & .065 & -.006 & $-.078^{*}$ & $-.141^{*}$ \\
$\mathrm{~T}-2$ & .010 & $.149^{*}$ & -.974 & .080 & -.019 & $-.063^{*}$ & $-.182^{*}$ \\
$\mathrm{~T}-1$ & $-.078^{*}$ & $.188^{*}$ & -1.174 & .104 & $-.026^{*}$ & -.026 & $-.204^{*}$ \\
\hline
\end{tabular}

Note. $*$ significant at $5 \%$ level. 


\section{Conclusion}

We analyze the change in behavior of certain governance characteristics for delisting firms in China and compare these firms with a set of size and industry matched control firms. We conclude that the shareholders of delisted firms are significantly passive compared to the surviving firms and the gap widens as the delisted firms approach actual delisting event. Overall, we confirm a significant negative relation between shareholder activism and events of delisting in China. Consistent with our expectation, the board activity of delisting firms increases as they approach actual delisting event while the board activity of surviving firms remains unchanged. Indeed, the difference in board activity of delisting and surviving firms is significantly large at period T-2 with delisting firms exhibiting higher level of activity. Charitou (2007) found a similar increase in board activity but at period $\mathrm{T}-1$. We observe that in the case of China the board activity increases as early as two years before delisting. The increase in board activity at period T-2 and T-1 may be attributed to board's response to adverse performance of the firms resulting in an increase in probability of delisting. For our sample, there is no significant difference in delisting and surviving firms with regard to presence of audit committee during the three years preceding delisting. These results are inconsistent with the findings of Mangena and Chamesa (2008). Intuitively, we infer that the role of audit committees in Chinese corporate governance mechanisms is less effective as compared to other developed countries of the world and hence it does not contribute significantly towards prevention of involuntary delisting in China. Our findings on board size reflect that there is no significant difference in the board size for delisting and surviving firms. Our findings are consistent with previous literature that board size is not a significant determinant of involuntary delisting (Charitou et al., 2007; Mangena \& Chamisa, 2008).

Our results show that board independence increase significantly for the delisting firms from period T-3 to period T-1. However, the board independence for surviving firms also increased during this period and there is no significant difference in the board independence between delisting and surviving firms. We show that board independence has a significant negative impact on the probability of delisting in China at period T-1, however, its impact is not significant in the earlier years. These finding are consistent with Charitou et al. (2007) and Mangena and Chamisa (2008) that the percentage of outside directors is significantly negatively related with delisting. When we compare ownership concentration of delisting and surviving firms we find the difference to be significant at period T-3 and highly significant at period T-2 and period T-1with surviving firms exhibiting more concentrated ownership. Consistent with our expectation, we find ownership concentration to have a significant negative impact on the probability of delisting in China. Our results are in line with previous literature on ownership concentration that builds its argument on agency theory (Jensen \& Meckling, 1976; Demsetz, 1983; Shleifer \& Vishny, 1986). When we compare insider ownership of delisting and surviving firms we find the difference to be constantly increasing and significant during the three years prior to delisting. Consistent with our expectation, insider ownership has significant negative association with the probability of delisting in China in all three years prior to delisting. Our results on insider ownership are consistent with Charitou et al. (2007) but different from Mangena and Chamisa (2008) who find no association between insider ownership and incidences of involuntary delisting on South African stock exchange.

Insider ownership, together with ownership concentration, is the most important variable in predicting delisting events in China. We broadly conclude that in case of China, ownership characteristics are more significant in distinguishing delisting firms from surviving firms compare to board characteristics. An explanation of this phenomenon may require further investigation of the board characteristics, board effectiveness and peculiar features of corporate governance practices in China.

\section{References}

Ajinkya, B., Bhojraj, S., \& Sengupta, P. (2005). The association between outside directors, institutional investors and the properties of management forecasts. Journal of Accounting Research, 43(3), 343-376. http://dx.doi.org/10.1111/j.1475-679x.2005.00174.x

Altman, E. I. (1968). Financial ratio, discriminant analysis and the prediction of corporate bankruptcy. Journal of Finance, 23, 589-609. http://dx.doi.org/10.1111/j.1540-6261.1968.tb00843.x

Baek, J., Kang, J., \& Park, K. S. (2004). Corporate governance and firm value: Evidence from the Korean financial crisis. Journal of Financial Economics, 71, 265-313. http://dx.doi.org/10.1016/S0304-405X(03)00167-3

Beasley, M. (1996). An empirical analysis of the relation between the board of director composition and financial statement fraud. Accounting Review, 71, 433-465.

Black, B. S. (1998). Shareholder activism and corporate governance in the United States. The New Palgrave Dictionary of Economics and the Law, 3, 459-465. 
Burns, R. P., \& Burns, R. (2009). Business research methods and statistics using SPSS. SAGE Publications.

Cabrera, A. F. (1994). Logistic regression analysis in higher education: An applied perspective. Higher Education: Handbook of Theory and Research, 10, 225-256.

Charitou, A., Louca, C., \& Vafeas, N. (2007). Boards, ownership structure, and involuntary delisting from the New York Stock Exchange. Journal of Accounting and Public Policy, 26, 249-262. http://dx.doi.org/10.1016/j.jaccpubpol.2007.02.006

Cleary, P. D., \& Angel, R. (1984). The analysis of relationships involving dichotomous dependent variables. Journal of Health and Social Behavior, 25, 334-348. http://dx.doi.org/10.2307/2136429

Cox, D. R., \& Snell, E. J. (1989). The analysis of binary data (2nd ed.). London: Chapman and Hall.

Daily, C. M., \& Dalton, D. R. (1994). Bankruptcy and corporate governance: The impact of board composition and structure. Academy of Management Journal, 37(6), 1603-1617. http://dx.doi.org/10.2307/256801

Dechow, P. M., Sloan, R. G., \& Sweeny, A. P. (1996). Causes and consequences of earnings manipulation: An analysis of firms subject to enforcement action by the SEC. Contemporary Accounting Research, 13(1), 1-36. http://dx.doi.org/10.1111/j.1911-3846.1996.tb00489.x

Demsetz, H. (1983). The structure of ownership and the theory of the firm. Journal of Law and Economics, 26(2), 375-390. http://dx.doi.org/10.1086/467041

Eisenberg, T., Sundgren, S., \& Wells, M. (1998). Larger board size and decreasing firm value in small firms. Journal of Financial Economics, 48, 35-54. http://dx.doi.org/10.1016/S0304-405X(98)00003-8

Fama, E. F., \& Jensen, M. C. (1983). Separation of ownership and control. Journal of Law and Economics, 26, 301-325. http://dx.doi.org/10.1086/467037

Gillan, S., \& Starks, L. T. (1998). A Survey of shareholder activism: motivation and empirical evidence. http://dx.doi.org/10.2139/ssrn.663523

Goktan, M. S., Kieschnick, R., \& Moussawi, R. (2006). Corporate governance and corporate survival. Working paper, University of Texas at Dallas.

Goodstein, J., Gautum, K., \& Boeker, W. (1994). The effect of board size and diversity on strategic change. Strategic Management Journal, 15, 241-250. http://dx.doi.org/10.1002/smj.4250150305

Haniffa, R., \& Hudaib, M. (2006). Corporate governance structure and performance of Malaysian listed firms. Journal of Business Finance and Accounting, 33, 1034-1066. http://dx.doi.org/10.1111/j.1468-5957.2006.00594.x

Harris, J., Panchapagesan, V., \& Werner, I. M. (2008). Off but not gone: A study of Nasdaq delistings. Ohio State University Working Paper.

Ho, C., \& Williams, S. (2003). International comparative analysis of the association between board structure and the efficiency of value added by a firm from its physical capital and intellectual capital resources. International Journal of Accounting, 38, 465-491. http://dx.doi.org/10.1016/j.intacc.2003.09.001

Jarrell, G. A. (1984). The stock price effects of NYSE de-listing for violating corporate governance rules. U.S. Securities and Exchange Commission Working Paper.

Jensen, M. C. (1993). The modern industrial revolution, exit, and the failure of internal control systems. Journal of Finance, 48, 831-880. http://dx.doi.org/10.1111/j.1540-6261.1993.tb04022.x

Jensen, M. C., \& Meckling, W. H. (1976). Theory of the firm: Managerial behavior, agency costs and ownership structure. Journal of Financial Economics, 3(4), 305-360. http://dx.doi.org/10.1016/0304-405X(76)90026-X

Karamanou, I., \& Vafeas, N. (2005). The association between corporate boards, audit committees, and management earnings forecasts: An empirical analysis. Journal of Accounting Research, 43(3), 453-486. http://dx.doi.org/10.1111/j.1475-679X.2005.00177.x

Karpoff, J. M. (2001). The Impact of Shareholder Activism on Target Companies: A Survey of Empirical Findings. Retrieved from http://ssrn.com/abstract=885365

Klein, A. (1998). Firm Performance and Board Committee Structure. Journal of Law and Economics, 41, 275-299. http://dx.doi.org/10.1086/467391

Klein, A. (2002). Audit committee, board of director characteristics, and earnings management. Journal of Accounting and Economics, 33, 375-400. http://dx.doi.org/10.1016/S0165-4101(02)00059-9 
Long, J. S. (1997). Regression models for categorical and limited dependent variables. Thousand Oaks, CA: Sage.

Macey, J., O'Hara, M., \& Pompillo, D. (2005). Down and out in the stock market: The law and finance of the delisting process. Cornell University Working Paper.

Mangena, M., \& Chamisa, E. (2008). Corporate governance and incidences of listing suspension by the JSE Securities Exchange of South Africa: An empirical analysis. The International Journal of Accounting, 43, 28-44. http://dx.doi.org/10.1016/j.intacc.2008.01.002

Mangena, M., \& Pike, R. (2005). The effect of audit committee shareholding, financial expertise and size on interim financial disclosures. Accounting and Business Research, 35(4), 327-349. http://dx.doi.org/10.1080/00014788.2005.9729998

McConnell, J. J., \& Servaes, H. (1990). Additional evidence on equity ownership and corporate value. Journal of Financial Economics, 27, 595-612. http://dx.doi.org/10.1016/0304-405X(90)90069-C

Morck, R., Shleifer, A., \& Vishny, R. W. (1988). Management ownership and market valuation. Journal of Financial Economics, 20, 293-315. http://dx.doi.org/10.1016/0304-405X(88)90048-7

O'Donnell, J. L. (1969). Case evidence of the value of a new stock exchange listing. Michigan State University Business Topics, 15-21.

Ohlson, J. A. (1980). Financial Ratios and the probabilistic prediction of bankruptcy. Journal of Accounting Research, 18(1), 109-131. http://dx.doi.org/10.2307/2490395

Panchapagesan, V., \& Werner, I. M. (2004). From pink slips to pink sheets: Market quality around delisting from NASDAQ. Working Paper, Olin School, Washington University, St. Louis.

Peasnell, K. V., Pope, P. F., \& Young, S. (2001). The characteristics of firms subject to adverse rulings by the Financial Reporting Review Panel. Accounting and Business Research, 31(4), 291-311. http://dx.doi.org/10.1080/00014788.2001.9729621

Peng, C. Y., Lee, J., Kuk, L., \& Ingersoll, G. M. (2002). An Introduction to Logistic Regression Analysis and Reporting. The Journal of Educational Research, 96(1), 3-14. http://dx.doi.org/10.1080/00220670209598786

Raheja, C. (2005). Determinants of board size and composition: A theory of corporate boards. Journal of Financial and Quantitative Analysis, 40(2), 283-306. http://dx.doi.org/10.1017/S0022109000002313

Romano, R. (2000). Less is more: Making shareholder activism a valued mechanism of corporate governance. Yale Law \& Economics Research Paper No. 241.

Sanger, G. C., \& Peterson, J. D. (1990). An empirical analysis of common stock de-listings. Journal of Financial and Quantitative Analysis, 25, 261-272. http://dx.doi.org/10.2307/2330828

Shivdasani, A. (1993). Board composition, ownership structure and hostile takeovers. Journal of Accounting and Economics, 16, 167-198. http://dx.doi.org/10.1016/0165-4101(93)90009-5

Shleifer, A., \& Vishny, R. (1986). Large shareholders and corporate control. Journal of Political Economy, 94, 461-488. http://dx.doi.org/10.1086/261385

Short, H., \& Keasey, K. (1999). Managerial ownership and the performance of firms: Evidence from the UK. Journal of Corporate Finance, 5, 79-101. http://dx.doi.org/10.1016/S0929-1199(98)00016-9

Vafeas, N. (1999). Board meeting frequency and firm performance. Journal of Financial Economics, 53, 113-142. http://dx.doi.org/10.1016/S0304-405X(99)00018-5

Weir, C., Laing, D., \& McKnight, P. J. (2002). Internal and external governance mechanisms: Their impact on the performance of large UK public firms. Journal of Business Finance \& Accounting, 29(5\&6), 579-611. http://dx.doi.org/10.1111/1468-5957.00444

Yermack, D. (1996). Higher Market Valuation of Companies with a Small Board of Directors. Journal of Financial Economics, 40(2), 185-212. http://dx.doi.org/10.1016/0304-405X(95)00844-5

Note

Note 1. CSRC-China Securities Regulatory Commission. 


\section{Copyrights}

Copyright for this article is retained by the author(s), with first publication rights granted to the journal.

This is an open-access article distributed under the terms and conditions of the Creative Commons Attribution license (http://creativecommons.org/licenses/by/3.0/). 